\section{AMERICAN CONTACTS \\ WITH THE EASTERN CHURCHES 1820-1870}

By P. E. Shaw, $\$ 2.00$

A history of the Greek Mission of the Protestant Episcopal Church, the Episcopal Mission to Constantinople, the work of the A. B. C. F. M. in Turkey and Greece and a history of the indigenous Greek Evangelical Church by an author well-qualified to write on the subject. Most timely in view of the present interest in ecumenical Christianity.

\section{CONGREGATIONALISM \\ IN THE DUTCH \\ NETHERLANDS}

By Raymond P. Stearns, $\$ 2.00$

The author presents hitherto unpublished documents relating to the English Congregationalists in Holland. New light on the history of Congregationalism.
EPISCOPAL

APPOINTMENTS

IN THE REIGN

OF EDWARD II

By W. E. L. Smith, $\$ 1.50$

An exhaustive study based almost entirely upon original material, and filling a need which has not been met hitherto by any other work.

\section{THE GREAT AWAKENING}

IN NOVA SCOTIA 1776-1809

By Maurice W. Armstrong, $\$ 2.00$

An original study of the extension of the Colonial Great Awakening into Nova Scotia, with particular emphasis upon the life and work of Henry Alline. Other important leaders are given consideration as well.

\title{
IMPORTANT NOTICE
}

All who order a copy of Maurice W. Armstrong's

The Great Awakening in Nova Scotia

are offered a $50 \%$ discount on the other three previously published books advertised on this page.

These prices (postage additional) are valid only on direct orders from

\section{THE AMERICAN SOCIETY OF CHURCH HISTORY}

55 Elizabeth Street

Hartford 5, Conn. 